\title{
The Life History of a College Nursing Professor: Building a Professional Identity
}

\author{
Pedro J. Canto-Herrera, Mario A. Tejada-Loria, Juanita Rodríguez-Pech \\ $U A D Y$
}

\begin{abstract}
The review of the literature shows that their own teaching and learning experiences shape university professors' formation of their professional identity. This paper examines university professors' professional identity through life history. A qualitative approach was used, and the methodology employed was life history to gather events and happenings in people's lives as their data and then use analytical procedures to produce explanatory stories. One case was selected because it is a typical representative from a class of nursing faculty who has joined in the last five years at the University of Southern Mexico. The results were analyzed taking into account the basis of identity proposed by Burke and Stets (2009).
\end{abstract}

\section{Introduction}

Previously, research has shown that their own teaching and learning experiences shape university professors' formation of their professional identity. However, certain critical experiences may trigger an active construction of professional identity [1].

Meanwhile, Beijaard, Meijer, and Verloop [2] classified research on professional identity of professors in three categories: (a) how identity is formed, (b) identifying characteristics, and finally, (c) how it is presented in the stories of teachers. This study is related to the first category, how identity is formed, and coinciding with Lopez [3], in that "more than on one's own identity, the focus is on the process of formation and construction of identity in relation to how others view this process and how it is mutually recognized".

The main reasons why an individual chooses to be a university professor can be grouped into two categories. The first reported having had positive experiences with professors and teaching situations, and the second relates to one's own "natural" attributes to become a teacher- how they felt they were "born to be a professor". Their confidence about knowing what teaching is and what they need relates to their core beliefs and experiences built up through their education.

Teacher identity indicates how one identifies with being a professor and how one feels as a professor, so that teacher identity is based on the core beliefs one has about teaching and being a teacher; beliefs that are continuously formed and reformed through experience. It is possible to become an expert practitioner by actually doing the job, by performing the skills, but true professional teaching involves another dimension, an intellectual dimension.

In this regard, we have tried to address the concern of Beijaard, Meijer, and Verloop [2] to understand the role of context in the process of constructing a teacher identity. Thus the purpose of this study is twofold: firstly to gain an understanding of one professor's perception of how they feel about teaching prior to starting their professional development, and secondly to understand how the professor constructs his professional identity.

Today the development of professional identity is a relevant problem because it articulates the axis of the professionalization of teachers (Fernandez, [4]). The stories of the early years as a university professor are essential for a better understanding of how identity is constituted by professional teachers who have had no special training for teaching and also have little experience in the professional field.

McCarthey and Moje [5] mention that studying identities is important because, first, identities typify the practices of people, secondly, because it helps people to be understood by others in more particular ways, and thirdly, because people act towards others depending on how they understand and position themselves amongst each other.

This study hopes to add to existing knowledge and current research concerning professional identity, novice teacher development, and finally, the process of constructing professional identity.

\section{Review of literature}

According to Lopes and Pereira [6] there are three perspectives regarding teacher identity recognized in literature: (a) situated identity, (b) psychosocial identity, and finally, (c) identity as an ecological construct. Here identity is taken as an ecological construct [7] [8] that refers to how personal identity and different social identities are organized within a situation that is framed in a cultural, social, organizational and political context.

Forming a teacher identity is a complex and culturally-based process, which occurs within a specific context, time, and place within multiple learning institutions [9].

Beijaard, Meijer, and Verloop [2] confirm that the concept of identity has different meanings in literature, although most researchers agree with Erikson or Mead's definition of the construct. However, as mentioned by the same authors, this 
diversity of meanings shares the common concept that identity is a relational phenomenon, that is, it is not an attribute that a person receives, but rather what arises in interaction with their social environment.

Likewise, the concept of professional identity has been defined in many ways, but is usually found in literature as related to the concept or image of one's self. In other studies it can be found as defined in relation to the position of the role of the teacher and to other positions that consider a wider field of relations [2].

In this paper, the concept of "professional identity" refers to a specific field or area of performance. It should be conceived as alluding to a dynamic and interactive process of construction, in which variables converge that are somewhat subjective and social in nature (personal and collective histories of the informants). Professional identity can also be understood as a process of identification or constructing identity under reference models, and other elements, biographical or personal in nature.

According to Dunbar (cited in Bolivar, [10]), in order to put these processes into practice, professionals provide a legitimate discourse whose aim is to demonstrate the presence of content such as: skills, values, challenges, etc., and that embodies a particular and exclusive character, allowing for domain (self-perception) and recognition (social / official).

One professor has many identities or forms to be defined within the areas of socialization [11]. Woods [12], for example, refers to the existence of "substantial" and "situational" identities, establishing a framework of differences in terms of duration, strength and positioning. The first one refers to the distinctive elements that remain independent of any context, including time, and immune to any assignment, that instead appears reasserted in their interaction. The second specifies the installation of transient factors, which are constantly modified, as noted, under the contexts of socialization.

We agree with Tardif's [13] point of view regarding the existence of a plural professional identity, that an individual can have more than one professional identity, characterized by the existence of a highly transversal nucleus, which gives meaning and direction to the peripheral professional identities.

Professional identity is defined as the result of the articulation of the biographical and relational dimensions in the mark of specific contexts within which the subject transits [10].

We also agree with Dunbar's point of view in that the biographical dimension is the identity for oneself, that is, how the individual takes on what one has been and what one wants to be; and, moreover, the relational dimension is the identity for others.
The process of becoming a teacher is a contextualized one, according to McLean [14]. Professional identity develops over time, and involves gaining insights into the professional practices and the values, skills, and knowledge required and practiced within the profession; in other words, the teachers' past and present experiences as well as their experiences with places of teaching and learning (i.e. their own educational experiences) influence the choices made by the student teacher in choosing to enter the teaching profession.

\section{Objectives}

This paper is based on an inquiry that was guided by the following objectives:

1. To examine the professional life histories of selected professors to determine the extent to which they reflect the construction of professional identity. 2. To explore the complex interplay in the form and way of constructing professional identity.

\section{Method}

Qualitative researchers use the life history approach to gather events and happenings in people's lives as their data and then use analytical procedures to produce explanatory stories [15]. The qualitative, interpretive approach was chosen because it describes and analyzes people's individual and collective social actions, beliefs, thoughts, experiences, views, and perspectives. The use of the qualitative research method, furthermore, provided this paper direct, firsthand, and more contextual information about professional identity.

The methodology employed in this work was life history, because as stated by Bolivar [10] it is the best way to reconstruct the identity narrative, because it is through stories that we give an identity. In addition, the narrative (Riessman as cited in Bathmaker, [16]) permits us to be involved (as researchers and / or observers) with the perspective of the one who tells the story.

Life history analysis is about making sense of a story. It includes brooding and reflecting upon all the data that has been collected. The raw data has been analyzed in terms of the key ideas and themes that flow from the story [17].

The case of Juan Carlos was selected because it is a typical representative of a class from the nursing school who has joined in the last five years at the University of Southern Mexico. Professors who have been trained as nurse practitioners but are not practicing in their field and now serve as trainers for new nurses characterize this group.

Juan Carlos is 28 years old. He is the son of a traditional middle class family from the interior region of the state. His father has a food business that he has dedicated his entire life to, and his mother is a 
housewife. His parents did not complete basic education. However, the cultural capital of the mother and the unconditional support of the father, as well as some key figures who influenced his family and personal life, made academic training a priority for the family and for Juan Carlos himself above any other activity. This is evident, for example, when Juan Carlos was sent away to study, beginning at the high school level, far from his family and his community.

In 2008 Juan Carlos was one of the $61 \%$ of Mexicans who graduated from a public university (Organization for Economic Cooperation and Development [OECD], 2008, "College students do not complete their studies," p. 6) but furthermore he was one of the $40 \%$ of people from his class in his native town to achieve a university degree, and is the only one from his community currently working at a university.

The information with which we build the life history of Juan Carlos was collected through three in-depth interviews. In total, we recorded 365 minutes, of which $96 \%$ of the recording is the narrative of Juan Carlos and only $4 \%$ represents interventions from one of the interviewers.

The analysis of data was arranged in themes, which are regarded as important and relevant areas or events in the life of Juan Carlos. The main aim for engaging in the thematic field analysis was to identify emerging trends and patterns in the responses of Juan Carlos and thus to formulate conclusions based on general patterns and trends.

\section{Results}

The results were analyzed taking into account the basis of identity proposed by Burke and Stests [18], considering identity from its group and individual social roles. We found that professional identity for a university professor is not made up only of traditional forms being repeated by their colleagues or other teachers, or by accepting certain social roles such as a professor, or by being identified as part of a group of teachers, but by the capacity to identify as one of them, while at the same time respecting one's own individuality.

Textual analysis was conducted using TextStat software version 2.9. It began with an analysis of frequencies of the words used. It was found that the speech transcripts of Juan Carlos from the threerecorded interviews consist of 4,116 words that are repeated at different frequencies with up to a total of 37,374 mentions. That is, an $11.01 \%$ utilization of oral language

On the other hand, the speech of Juan Carlos is personal and thoughtful, this can be verified taking into account the frequent use of the personal pronoun "I", the possessive adjective "my", the personal pronoun "I", as well as the personal pronoun "me".
All these words are among the ten most frequently used and are associated with the theme of identity, as they refer to awareness of self as an object and person at a time (Burke and Stets, [18] through the story. That is, by using these language symbols Juan Carlos manages to make a push for himself as a character narrating a story, his own life story.

Moreover, among the ten most frequently used words, it was found that Juan Carlos uses some words in his narrative to refer to other actors in his life such as: mom, teachers, and students. These symbols of language that Juan Carlos used to refer to other characters in his life story show some of the relevance of these actors in his narrative. Importantly, not among the top ten most frequently used words are the words "nurse" and "nursing", ie Juan Carlos referenced his profession of origin and role as a nurse to a lesser extent in his speech. This may be because Juan Carlos has not acted as a nursing professional and therefore lacks the models from this professional field, while he mentions more about his career as a teacher and on some models he admires. This is to be expected considering that Juan Carlos began his professional life working for the university.

In additional analysis of words used, we conducted a narrative analysis of the life histories produced.

Verification of the role as a university professor was the first category in the analysis. At this respect, Juan Carlos said that his college entrance as a university professor was something unplanned for him and stemmed from his performance in a workshop he gave at a national nursing conference:

"I finished my thesis and [was] in a well-known Conference [in 2008] where I talked with the principal of the nursing school, I think he was very smart, because he quickly moved his influences..." (Juan Carlos, 24 November 2012).

[Then] "(...) you're invited to participate as part of the teaching staff of the college. I guess it's because you have all these tools and teaching skills to convey information and then you think, I can learn to be a teacher"(Juan Carlos, March 10, 2012).

"It scared me, so much that my first impulse was to turn down offer, but I was thinking a mile a minute when I was talking with the coordinator of teaching. I remember that I said I am not a teacher, I do not know how to teach. I clearly remember she told me, we all start like that, and nobody starts out as a teacher. A little scared, I told her, that because the students were going to be my age. She said she knew that, but that was to be up to me, I had to place my limits"(Juan Carlos, November 24, 2012).

From Burke and Stests [18] theoretical perspective, when Juan Carlos enters into the College of Nursing, he has not completed a verification process of the teacher role, in other words, he feels guilt and discomfort because he feels 
incompetent for the position for which he was hired and also as a person, he feels sadness and depression for not identifying himself as a university professor.

"I was not born to be a professor and I was not trained to be one. I am licensed in the health area. It is true that you teach, because even when we are in the hospital we teach specific things to our colleagues in other semesters, but you don't have the responsibility to actually educate another person". (Juan Carlos, 10 March 2012).

"Something to remember and that was also a very important point for me was that for a subject (...) I was sent to work to a hospital. The coordinator sent me a month in the area [of the subject] that I had at the time, to return to retake that part and that's really helped me a lot. It helped me to take lessons, because it allowed me to present my students actual cases "(Juan Carlos, March 10, 2012).

Juan Carlos also mentions that continuing his professional training helped him feel more confident in his performance as a teacher.

"When I started studying the Masters in Epidemiology is when I said, now I can teach this subject ... which, I was told that the teacher who taught it was not specialized in the area. I went and made a deal with the teaching coordinator and she accepted that I give the course. That's when I started to say I am a university professor. I know I'm lacking, lacking teaching techniques, but I can already be telling the students a lot. Now I can be together with them building... because I sent them to top level centers with epidemiologists and others. I had come with such situations and now I knew I could do it. That is one part that marks me, when I decided I have to overcome this challenge and start my training "(Juan Carlos, November 24, 2012).

As can be seen, Juan Carlos verifies the role of his identity as a university professor, making him feel more self efficient for the professional activity of a university professor [18].

Verification with the group of university professors

Juan Carlos believes that recognition of his work in the epidemiological area by authorities and groups of teachers with extensive experience, was a fundamental support to continue in what he liked to do:

"One thing that drove me, now that I look back, was when I published an article in a well-known magazine and the teaching coordinator saw it unintentionally. Then she spoke to me and asked me about the article and congratulated me. That's something that motivates you and makes you continue in research and teaching "(Juan Carlos, November 24, 2012).

"Another [event] that impacted me ... is when I was invited to participate in an academic group as a collaborator (...). Then, as I was more involved in supporting epidemiological research in the school ... drawing from Dr. Emilio, apart from my other colleagues of the department of the Ministry of Health, (...) is another point where you gain strength "(Juan Carlos, November 24, 2012).

Juan Carlos recognizes that he has positioned himself inside and outside of the college of nursing. Despite his short career, students, colleagues and researchers from other institutions recognize him. However, he admits that he is still in training.

It is in recognition from his colleagues and authorities where he begins to feel part of the teaching staff of the College of Nursing, that is, where he begins to develop, as Burke and Stests [18], complementarity with the others:

"There was a situation where a colleague had many doubts about [a topic of epidemiology] and approached me. I began to wonder why he came to me and not to someone else. Why? Because the students, in trying to be better in the classroom and that (...) they respect you and link you to that area, [then] word starts to spread. And when your colleagues see that you are being consistent in the area and they link you ... and they see here are all my files and ... I'm writing, I'm analyzing, they approach you and ask you for help, or they ask you questions regarding doubts and things "(Juan Carlos, March 10, 2012)

"You grow as part of the team [of teachers], you're training yourself, you're growing and therefore now they recognize your work. You even feel embarrassed sometimes, because they say you're the expert in this area, and you say, how ironic. But I think it is wise to acknowledge the work of others "(Juan Carlos, March 10, 2012)

Therefore, it can be concluded that with respect to the verification of the group, Juan Carlos showed that his self-esteem increased in situations where his role as a university professor was recognized, and the respect his peers began to have him for the professional performance he demonstrated. This coincides with Burke and Stests [18] regarding the verification of social identity in relation to the group.

Personal verification as a university professor

This type of verification was the most difficult for us to locate within Juan Carlos' discourse. However, reflecting meta cognitively with him, we were able to understand that it is indeed present in his narrative.

Burke and Stests [18] mention that the result of the verification of identity with a personal basis occurs when authenticity is generated, that is one's own way of being and doing, constructed by the individual in the environment in which one develops.

Juan Carlos' process of identification as the teacher he wanted to be, was not easy. Increasingly interested in the academic profession, he became involved in research funded by renowned researchers, who invited him to participate as a collaborator. But the stereotype of the traditional nurse, dedicated to studying care, was a discussion 
that he had to overcome with his effort and work to show that the path he had chosen was correct.

"(...) When [traditional teachers] see I'm studying more about epidemiology they ask me why I want to know so much about it? I told them because I like it. [But] they told me I should have studied [originally] something about [that] (...). But no, I like my discipline. I mean, I like my job [as a nurse] and I love my career field. Aside from that they would say, you are not a teacher from the area. [But] I always questioned them [the] why I was not. They responded, because you are not teaching nursing as such "(Juan Carlos, March 10, 2012).

But Juan Carlos remarks that even the iconic figure of nursing, Florence Nightingale, did more than just engage in the care of soldiers at war. She trained women to serve as nurses and did research to build theories and models of patient care.

As was observed, Juan Carlos challenges the traditional view of nurses dedicated to the clinical side. For this he suggests his own way to understand his profession through research and teaching. He links both activities directly to the essential work of nursing.

However, the likely difficulty mentioned in the paragraph initially is because the personal verification of a role to achieve authenticity is perhaps the most complicated and interesting process in the development of a professional identity.

\section{Conclusion}

Two forms of identification can be perceived in the story that Juan Carlos tells: (1) community and (2) corporate. In the first type, community develops during his childhood, even before leaving his community, and the second type, corporate, occurs upon arrival to the city to study and continues into the present. In other words, Juan Carlos went from one form of identification, determined by his community, to one in which he, as a social agent, had to develop his individuality to stand out from the others.

Also, in the case of Juan Carlos, more than a professional identification process, where he only acquires certain characteristics or behaviors typical of a particular group, another process occurs at the same time. This is a process of identity differentiation, where it is not enough to just find oneself and acquire a role for a position in the social structure, it is necessary to legitimize and find a place within the group.

It is important to note that the institution where Juan Carlos works has an important role in the reconstruction of his professional identity as a university professor because it was an educational institution that supported listening so that he could acquire necessary experiences that helped in the development of his skills as a teacher. Otherwise
Juan Carlos would not have had the opportunity to express his ideas and make proposals that allowed him to successfully integrate into academic life and thus avoid having to quit his job.

As a final conclusion, despite much research indicating that the individual maturation process of the teacher professional identity begins during the teacher preparation stage, according to the discourse analyzed here, we conclude that teacher identity may be developed later, during the initial teaching stage.

\section{References}

[1] Chong, S.; Ling, L. E. and Chuan, G. K. (2011). Developing student teachers' professional identities. An exploratory study. International Education Studies, 4 (1), 30-38.

[2] Beijaard, D.; Meijer, P.C. and Verloop, N. (2004). Reconsidering research on teachers' professional identity. Teaching and teacher education, 20, 107-128. doi: 10.1016/j.tate.2003.07.001.

[3] López, A. (2011). Las historias de vida en la formación docente: orígenes y niveles de la construcción de identidad de los profesores. In: F. Hernández, J.M. Sancho and J.I. Rivas (Eds.), Historias de vida en educación. Biografías en contexto (pp. 23-33) [Adobe Digital Editions version]. http://diposit.ub.edu/dspace/handle/2445/15323.

[4] Fernández, M. (2010). Aproximación biográficonarrativa a la investigación sobre formación docente. Profesorado. Revista de Currículum y Formación del Profesorado, 14 (3), 17-32. Retrieved from: http://www.ugr.es/ recfpro/rev143ART1.pdf.

[5]McCarthey, S.J. and Moje, E.B. (2002). Identity matters, Reading Research Quarterly, 37 (2), 228-238.

[6] Lopes, A and Pereira, F. (2013). Especificidades de la formación de profesores y profesión docente: reflexiones a partir de un estudio sobre los formadores de profesores y de enfermero. Comunicación presentada en Aprender a ser docente en un mundo en cambio, Barcelona, España. http://som.esbrina.eu/aprender/docs/1/LopesAmeliaPereira Fatima.pdf

[7] Lopes, A. (2008). Vale la pena formar profesores. Currículos de formación inicial y identidades profesionales de base. In M. B. Pardo, M.C. Galzerani \& A. Lopes (Dirs.). Una 'nueva'cultura para la formación de maestros: ¿es posible? (pp. 85-110). Lisboa: Legis Editora/UNESCO/AMSE-AMCE-WAER.

[8] Lopes, A. (2009). Teachers as Professionals and Teachers' Identity Construction as an Ecological Construct- an agenda for research and training drawing upon a biographical research process. European Educational Research Journal, 8 (3), 461-475.

[9] Danielewics, J. (2001). Teaching selves: identity, pedagogy, and teacher education. Albany, NY: State University of New York Press. 
[10] Bolívar, A. (2006). La identidad profesional del profesorado de secundaria: crisis y reconstrucción [Adobe Digital Editions version]. Retrieved from:: http://www.todoebook.com/LA-IDENTIDAD-

PROFESIONAL-DEL-PROFESORADO-DESECUNDARIA-ANTONIO-BOLIVAR-BOTIAEDICIONES-ALJIBE_-S_L_-LibroEbook-es9788497005654.html.

[11] Czop, L. (2008). Professional identity of a reading teacher: responding to high-stakes testing pressures. Teachers and teaching: theory and practice. 14 (3), 239252.

[12] Woods, P. and Jeffrey, B. (2002). The reconstruction of primary teachers' identities. British Journal of Sociology of Education. 23 (1), 89-106.

[13] Tardif, M. (2004). Los saberes del docente y su desarrollo profesional. Madrid: Narcea.

[14] McLean, V. (1999). Becoming a teacher. In R. P. Lipka \& T. Brinthaupt (Eds.), The role of self in teacher development. Albany, NY: State University of New York Press.

[15] Polkinghorne, D.E. (1995). Narrative Configuration in Qualitative Analysis. In: Hatch JA \& Wisnieswski R (eds). Life History and Narrative. London: Falmer Press.

[16] Bathmaker, A. (2010). Introduction. In A. Bathmaker and P. Harnett (Eds.), Exploring learning, identity and power through life history and life history and narrative research (pp. 1-10) [Kindle Editions version]. Retrieved from::

http://www.amazon.com/gp/product/B003AU7EQA/ref=d ocs-os-doi_0.

[17] Plummer, K (2001). Documents of Life 2: An Invitation to a Critical Humanism. London: Sage Publications.

[18] Burke, P.J. and Stets, J.E. (2009). Identity Theory [Kindle Editions version]. Retrieved from:: http://www.amazon.com/gp/product/B0055NCUAK/ref=d ocs-os-doi_0. 